\title{
Analisis Potensi, Efektivitas dan Kontribusi Pajak Restoran Kecamatan Kuta Utara pada Pendapatan Asli Daerah Kabupaten Badung
}

\author{
Ni Luh Risma Andika Dewi ${ }^{1}$ \\ Fakultas Ekonomi dan Bisnis \\ Universitas Udayana, Indonesia
}

\author{
Ni Made Dwi Ratnadi2 \\ Fakultas Ekonomi dan Bisnis \\ Universitas Udayana, Indonesia
}

\begin{abstract}
Surel : imaandika3@gmail.com
ABSTRAK

Tujuan penelitian ini adalah untuk mengetahui potensi pajak restoran, efektivitas pemungutan pajak restoran, dan kontribusi pajak restoran Kecamatan Kuta Utara terhadap Pendapatan Asli Daerah Kabupaten Badung. Penelitian ini dilakukan pada restoran di Kecamatan Kuta Utara berjumlah 185 wajib pajak Tahun 2019. Teknik analisis yang digunakan adalah analisis deskriptif kuantitatif yang dapat menghitung nilai potensi, efektivitas pemungutan, dan kontribusi pajak restoran di Kecamatan Kuta Utara. Hasil analisis menunjukan Potensi pajak restoran di Kecamatan Kuta Utara Tahun 2019 sebesar 212,7 persen dari realisasi pajak restoran di Kecamatan Kuta Utara Tahun 2018. Efektivitas pemungutan pajak restoran di Kecamatan Kuta Utara berdasarkan potensi pajak restoran Tahun 2019 sebesar 47,01 persen yang termasuk kriteria tidak efektif. Pajak restoran di Kecamatan Kuta Utara memberikan kontribusi sebesar 0,84 persen pada total penerimaan Pendapatan Asli Daerah (PAD) Kabupaten Badung Tahun 2018.
\end{abstract}

Kata Kunci: $\quad$ Pajak Restoran; Efektivitas; Potensi; Kontribusi.

\section{Analysis of the Potential, Effectiveness and Contribution of Restaurant Taxes in North Kuta District to the Original Revenue of Badung Regency}

\begin{abstract}
The purpose of this study was to determine the restaurant tax potential, the effectiveness of restaurant tax collection, and the contribution of restaurant tax North Kuta District to Local Revenue in the of Badung Regency. This research was conducted at restaurants in the North Kuta District totaling 185 taxpayers in 2019. The analysis technique used was a quantitative descriptive analysis that could calculate the potential value, effectiveness of collection, and restaurant tax contributions in the North Kuta District. The results of the analysis show the restaurant tax potential in the North Kuta District in 2019 amounted to 212.7 percent of the realization of the restaurant tax in the North Kuta District in 2018. The effectiveness of restaurant tax collection in the North Kuta District based on the potential restaurant tax in 2019 amounted to 47.01 percent which includes the criteria ineffective. Restaurant tax in North Kuta Subdistrict contributed 0.84 percent to the total Badung Regency Revenue in 2018.
\end{abstract}

Keywords: Restaurant Tax; Effectiveness; Potency; Contribution.

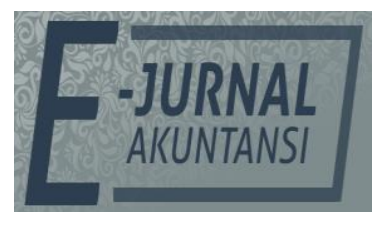

e-ISSN 2302-8556

Vol. 31 No. 2

Denpasar, Februari 2021

Hal. 275-287

DOI:

10.24843/EJA.2021.v31.i02.p01

PENGUTIPAN:

Dewi, N.L.R.A., \& Ratnadi, N.M.D. (2021). Analisis Potensi, Efektivitas dan Kontribusi Pajak Restoran Kecamatan Kuta Utara pada Pendapatan Asli Daerah

Kabupaten Badung. E-Jurnal Akuntansi, 31(2), 275-287

RIWAYAT ARTIKEL:

Artikel Masuk:

3 Desember 2019

Artikel Diterima:

19 Februari 2021

Artikel dapat diakses : https://ojs.unud.ac.id/index.php/Akuntansi/index 


\section{PENDAHULUAN}

Setiap daerah otonom dalam hal ini provinsi maupun kabupaten/kota di Indonesia, memiliki sumber daya alam dan potensi ekonomi yang bervariasi, sehingga jika dimanfaatkan dengan optimal maka akan mampu berkontribusi lebih signifikan, dalam penerimaan pendapatan asli daerah dengan tujuan memberikan kontribusi yang signifikan bagi penerimaan Pendapatan Asli Daerah (PAD), yang pada tujuannya akan memberikan manfaat dalam pembangunan daerah (Poulson \& Kaplan, 2008). Dalam rangka penyelenggaraan pembangunan dan menunjang pemerintahan daerahnya, pemerintah daerah berhak mengenakan pemungutan pajak daerah dan retribusi daerah kepada seluruh masyarakatnya (Tjip, 2011).

Pendapatan Asli Daerah (PAD) merupakan salah satu indikator untuk mengukur kemampuan dan kemandirian keuangan suatu daerah. Menurut Undang-Undang Nomor 33 Tahun 2004 Tentang Perimbangan Keuangan antara Pemerintah Pusat dan Pemerintahan Daerah, Pendapatan Asli Daerah adalah pendapatan yang diperoleh daerah yang dipungut berdasarkan peraturan daerah. Upaya peningkatan PAD melalui pajak ataupun retribusi daerah akan berhasil bila pemerintah daerah menunjukkan itikad yang sungguh-sungguh untuk meningkatkan pelayanan publiknya. Peningkatan pelayanan publik ini tercermin dengan meningkatnya proporsi belanja pembangunan (Wong, 2004).

Undang-Undang Nomor 28 Tahun 2009 tentang Pajak Daerah dan Retribusi Daerah mencantumkan definisi pajak daerah adalah kontribusi wajib kepada daerah yang terutang oleh orang prbadi atau badan yang bersifat memaksa berdasarkan undang-undang, dengan tidak mendapatkan imbalan secara langsung dan digunakan untuk keperluan daerah bagi kemakmuran rakyat. Pajak Daerah yang merupakan salah satu sumber penting dan utama dari Pendapatan Asli Daerah (PAD) yang akan sangat berpengaruh pada kinerja keuangan pemerintahan daerah. Jika pendapatan pajak daerah suatu daerah tinggi atau sesuai target yang ditetapkan, maka hal ini menunjukan kinerja keuangan yang bagus dari daerah tersebut.

Pajak daerah memiliki kontribusi yang amat penting bagi proses pembangunan suatu daerah. Kesanggupan pemerintah daerah untuk mengoptimalkan penggalian pajak daerah merupakan salah satu usaha pemerintah daerah dalam menerapkan otonomi daerah yaitu dengan membiayai rumah tangga daerah itu sendiri. Kabupaten Badung sebagai daerah otonomi diharuskan menanggung keperluan biaya rumah tangganya sendiri. Agar terlaksananya dengan lancar mengenai otonomi daerah tersebut, maka bagian pemerintah Kabupaten Badung perlu melakukan penggalian pajak yang dalam hal ini pajak daerah.

Kendala yang dihadapi pemerintah dalam pelaksanaan otonomi daerah adalah tingkat kesiapan keuangan yang berbeda pada setiap daerah. Kebijakan otonomi daerah merupakan kebijakan yang menguntungkan daerah-daerah yang mempunyai sumber daya potensial namun bagi daerah yang kurang memiliki sumber daya potensial menganggap kebijakan otonomi daerah merupakan kebijakan yang tidak menguntungkan (Norregaard, 2013). Penelitian Pepinsky \& Wihardja (2011) dan Aragon (2009) menjelaskan bahwa 
pemerintahan daerah memperoleh dana paling besar dari pajak daerah dan pemerintahan pusat.

Sumber penerimaan daerah yang potensial bagi Pendapatan Asli Daerah di Kabupaten Badung selain pajak hotel adalah Pajak Restoran, ini dikarenakan jumlah restoran di Kabupaten Badung khususnya di kecamatan Kuta Utara mengalami peningkatan setiap tahunnya. Peningkatan jumlah restoran di Kecamatan Kuta Utara, Kabupaten Badung merupakan hal positif bagi peningkatan Pendapatan Asli Daerah (PAD) Kabupaten Badung. Semakin banyak restoran semakin besar pula pemasukan untuk Pendapatan Asli Daerah (PAD) di Kabupaten Badung.

Kabupaten Badung memiliki kondisi geografis alam yang indah. Dengan keindahan alam menjadikan Kabupaten Badung sebagai jujukan wisata dari para wisatawan, baik wisatawan domestik maupun mancanegara. Kecamatan Kuta Utara merupakan salah satu kecamatan yang berada di wilayah Kabupaten Badung. Kecamatan Kuta Utara memiliki objek wisata yang sering dikunjungi oleh para wisatawan salah satunya adalah pantai batu bolong. Kondisi ini dapat membawa daya tarik bagi para pengusaha untuk membuka usahanya dalam bidang restoran. Dalam hal ini akan membantu pemerintah daerah kota wisata ini untuk melakukan kegiatan pembangunan dari hasil pemungutan pajak restoran tersebut. Dengan adanya pemungutan pajak restoran tersebut, diharapkan dapat membangun atau meningkatkan kondisi pembangunan atau ekonomi di Kabupaten Badung.

Salah satu tugas pemerintah daerah Kabupaten Badung adalah melaksanakan kegiatan pemungutan pajak restoran sehingga penting untuk mengetahui besarnya potensi pajak restoran yang sesungguhnya dimiliki oleh daerah yang dikelolanya agar dapat menentukan target penerimaan pajak restoran pada periode berikutnya dengan tepat. Kemampuan pemerintah daerah dalam merealisasikan penerimaan pajak restoran dibandingkan dengan target pajak restoran yang telah direncanakan menggambarkan efektifitas pemungutan pajak restoran.

Tabel 1. Target dan Realisasi Pajak Restoran di Kabupaten Badung Tahun Anggaran 2014-2018

\begin{tabular}{ccccc}
\hline Tahun & Target (Rp) & Realisasi (Rp) & $\begin{array}{c}\text { Perbandingan } \\
\text { Target dan } \\
\text { Realisasi (\%) }\end{array}$ & $\begin{array}{c}\text { Pertumbuhan } \\
\text { Realisasi (\%) }\end{array}$ \\
\hline 2014 & $204.000 .000 .000,00$ & $264.628 .244 .501,50$ & 70,28 & \\
2015 & $277.000 .000 .000,00$ & $323.911 .681 .347,84$ & 83,06 & 22,4 \\
2016 & $336.913 .444 .429,51$ & $400.430 .347 .729,69$ & 81,15 & 23,62 \\
2017 & $451.934 .732 .795,59$ & $475.939 .453 .837,24$ & 94,69 & 18,86 \\
2018 & $579.083 .731 .320,87$ & $624.456 .631 .009,54$ & 92,16 & 31,21 \\
\multicolumn{7}{l}{ Rata-rata laju pertumbuhan pajak restoran per tahun } \\
\hline
\end{tabular}

Sumber: Data Penelitian, 2019

Berdasarkan Tabel 1, dapat diketahui laju pertumbuhan Pajak Restoran dari tahun 2014 ke Tahun 2015 terjadi peningkatan realisasi pajak restoran dengan laju pertumbuhan sebesar 22,40 persen. Dari Tahun 2015 ke Tahun 2016 terjadi peningkatan realiasasi pajak restoran dengan laju pertumbuhan sebesar 23,62 persen. Dari Tahun 2016 ke Tahun 2017 terjadi peningkatan realisasi pajak 
restoran dengan laju pertumbuhan sebesar 18,86 persen. Dan dari Tahun 2017 ke Tahun 2018 terjadi peningkatan lagi pada realisasi pajak restoran dengan laju pertumbuhan sebesar 31,21 persen. Secara keseluruhan rata-rata laju pertumbuhan Pajak Restoran per tahun adalah sebesar 24,02 persen. Dari data tersebut maka dapat dilihat bahwa selama lima tahun terakhir pencapaian dan perkembangan realisasi pajak restoran selalu mengalami fluktuatif namun jumlah pendapatan yang di terima dari sektor pajak restoran selalu mengalami peningkatan dan Peningkatan laju pertumbuhan terbesar adalah di tahun 2018 sebesar 24,02 persen.

Potensi Pajak restoran sangat menentukan besarnya pajak daerah yang dapat dipungut, dengan demikian besarnya potensi pajak perlu diketahui untuk menetapkan besarnya target penerimaan pajak pada suatu periode. Hal ini akan memudahkan perencanaan dan mengendalikan pelaksanaan pemungutan pajak tersebut. Berdasarkan teori kepatuhan, apabila potensi pajak restoran yang ditemukan lebih besar, maka wajib pajak restoran mengalami kesadaran terhadap kewajiban perpajakannya yang telah ditetapkan oleh Undang-Undang.

Andeman (2001) melakukan penelitian Potensi Pajak Hotel dan Restoran di Kota Bukittinggi tahun 2000, yang menunjukan bahwa target Pajak Hotel di Kota Bukittinggi tahun 2000 sebesar Rp.725.000.000,- realisasi sebesar Rp.974.000.000,- dan potensi hasil perhitungan sebesar Rp.1.590.396.000. Hasil analisis menunjukan Realisasi Pajak Hotel mencapai 61,30 persen dari potensi yang ditemukan, dan Realisasi Pajak Restoran baru mencapai 15,83 persen dari potensi yang ditemukan. Berdasarkan penjabaran tersebut, dapat diduga bahwa, pajak restoran di Kecamatan Kuta Utara Kabupaten Badung memiliki potensi.

Efektivitas berarti tingkat pencapaian hasil program kerja dengan target yang ditetapkan. Tingkat efektifitas tersebut berhubungan dengan kedisiplinan dan pengawasan petugas lapangan dan kesadaran para pedagang di dalam pasar untuk membayar retribusi yang telah ditetapkan agar sesuai dengan target penerimaan dari pemerintah, tingkat efektifitas ini berhubungan dengan seberapa besar pengaruh retribusi pelayanan pasar pada pendapatan asli daerah (Kamaroellah, 2011). Berdasarkan teori kepatuhan, apabila nilai yang ditargetkan lebih kecil dari nilai realisasi yang diperoleh, maka wajib pajak restoran digolongkan sangat efektif terhadap kewajiban perpajakannya dengan tetap berdasarkan pada peraturan Perundang-Undangan yang telah ditetapkan.

Hasil penelitian Makalew, et al., (2018) yang berjudul Analisis Potensi Dan Efektivitas Penerimaan Pajak Restoran Di Kota Tomohon, tingkat efektivitas pajak restoran untuk tahun anggaran 2013-2016 penerimaan pajak restoran melebihi target yang ditetapkan pemerintah, sehingga tingkat efektivitas pajak restoran tahun anggaran 2013-2016 di Kota Tomohon dapat digolongkan "Sangat Efektif". Pada tahun 2013 terget pajak restoran yang ditetapkan pemerintah yaitu sebesar Rp.1.175.000.000 dan terealisasi baik dengan penerimaan sebesar Rp1.484.959.553 persentase 126,38 persen "sangat efektif", pada tahun 2014 target pajak restoran yang ditetapkan pemerintah sebesar Rp1.289.600.000 dan terealisasi dengan baik bahkan mengalami peningkatan penerimaan sebesar Rp2.140.442.860 persentase 165,98 persen "sangat efektif", pada tahun 2015 target pajak restoran yang ditetapkan pemerintah sebesar Rp1.858.600.000 dan terealisasi dengan baik dengan penerimaan sebesar Rp3.019.391.763 persentase 
162,46 persen "sangat efektif", dan pada tahun 2016 pemerintah menaikkan target pajak restoran menjadi Rp3.087.232.000 dan terealisasi dengan baik dengan penerimaan sebesar Rp3.451.597.137 persentase 111,8 persen "sangat efektif". Berdasarkan penjabaran tersebut, maka dapat diduga bahwa pemungutan pajak restoran di Kuta Utara sangat efektif.

Kontribusi pajak daerah merupakan sejauh mana porsi atau hasil/jumlah dana yang dikumpulkan dari sektor pajak di suatu daerah dibandingkan dengan jumlah total pendapatan daerah. Sehingga kontribusi yang dimaksud dapat diartikan sebagai sumbangan yang diberikan Pajak Daerah terhadap besarnya Pendapatan Asli Daerah (PAD). Berdasarkan teori kepatuhan, wajib pajak dapat meningkatkan kesadarannya dalam memenuhi kewajiban perpajakannya agar terciptanya target pajak yang diinginkan. Kontribusi dikatakan sangat baik, apabila realisasi penerimaan pajak restoran lebih besar dari realisasi penerimaan PAD.

Hasil penelitian Ardhiansyah (2014) kontribusi Pajak Hotel dan Pajak Restoran terhadap Pendapatan Asli Daerah Kota Batu pada tahun anggaran 2011-2013 kurang. Kontribusi pajak hotel tahun 2011 sebesar 11,19 persen, tahun 2012 sebesar 13,52 persen, tahun 2013 sebesar 11,05 persen. Kontribusi pajak restoran sangat kurang karena pada tahun 2011 sebesar 4,22 persen, tahun 2012 sebesar 4,37 persen, tahun 2013 sebesar 3,82 persen. Tingkat kontribusi yang lebih baik terdapat dalam pajak hotel. Berdasarkan penjabaran tersebut, maka dapat diduga bahwa terdapat kontribusi pajak restoran terhadap Pendapatan Asli Daerah Kabupaten Badung.

\section{METODE PENELITIAN}

Penelitian ini menggunakan metode analisis deskriptif kuantitatif yang menggambarkan perhitungan nilai yang artinya penelitian ini dilakukan untuk mengetahui potensi, efektivitas dan kontribusi pajak restoran terhadap Pendapatan Asli Daerah Kabupaten Badung. Lokasi penelitian ini dilakukan di Kecamatan Kuta Utara, Kabupaten Badung. Pemilihan Kecamatan Kuta Utara sebagai lokasi penelitian ini karena Kecamatan Kuta Utara merupakan Kecamatan yang wilayahnya memiliki banyak objek wisata seperti, pantai, wahana air, restoran, bar, beach club, dan lainnya. Penelitian di Kecamatan Kuta Utara dilakukan dengan cara pendataan dan pencatatan terhadap penerimaan pajak restoran tahun 2019.

Populasi dalam penelitian ini adalah Wajib Pajak Restoran seperti, restoran, rumah makan, bar dan jasa boga yang ada di Kecamatan Kuta Utara Kabupaten Badung, berjumlah 185 wajib pajak restoran. Dimana data tersebut diperoleh dari Dinas Pariwisata Kabupaten Badung. Metode yang digunakan dalam penelitian ini yaitu survei, observasi dan kuesioner. Sumber data dalam penelitian ini adalah data primer dan data sekunder. Data sekunder dalam penelitian ini diperoleh dari Dinas Pariwisata Kabupaten Badung, Dinas Pariwisata Provinsi Bali, Perbekel Desa Canggu, Kelurahan Kerobokan Kelod, dan https://www.zomato.com, https://www.tripadvisor.com. berikut.

Untuk menghitung potensi pajak restoran digunakan rumus, sebagai

Yit $=\mathrm{F} \times \mathrm{G} \times \mathrm{H}$ 
$\mathrm{F}=($ Jumlah kursi $\times \mathrm{JE} \times \mathrm{AR})+($ Jumlah kursi $\times \mathrm{JTE} \times \mathrm{AR})$.

Potensi Pajak Restoran $=$ Yit $\times$ Tarif Pajak

Keterangan :

Yit $\quad$ : jumlah pembayaran yang diterima untuk pajak restoran

$\mathrm{F} \quad$ : rata-rata pengunjung per hari

G : rata-rata harga

$\mathrm{H} \quad$ : jumlah hari

Tarif pajak $: 10 \%$

JE : jam efektif

JTE : jam tidak efektif

AR : Akupansi Rate

Untuk menghitung efektifitas pemungutan pajak restoran digunakan rumus sebagai berikut.

$$
\text { Efektivitas }=\frac{\text { Realisasi PajakRestoran }}{\text { Target Pajak Restoran }} \times 100 \%
$$

Tabel 2. Indikator Tingkat Efektivitas Pajak Restoran di Kecamatan Kuta Utara

\begin{tabular}{lll}
\hline No. & Presentase & Kriteria \\
\hline$>100 \%$ & Sangat Efektif \\
$100-90 \%$ & Efektif \\
$90-80 \%$ & Cukup Efektif \\
$80-60 \%$ & Kurang Efektif \\
$>60 \%$ & Tidak Efektif \\
\hline
\end{tabular}

Sunber: Mahmudi (2010:143)

Untuk menghitung kontribusi pajak restoran terhadap Pendapatan Asli

Daerah digunakan rumus sebagai berikut.

Kontribusi $=\frac{\text { Realisasi Penerimaan Pajak Restoran }}{\text { Realisasi Penerimaan PAD }} \times 100 \%$

Tabel 3. Klasifikasi Kriteria Kontribusi Pajak Restoran di Kecamatan Kuta Utara

\begin{tabular}{lll}
\hline No. & Presentase & Kriteria \\
\hline 1 & $>50 \%$ & Sangat Baik \\
2 & $40-50 \%$ & Baik \\
3 & $30-40 \%$ & Cukup Baik \\
4 & $20-30 \%$ & Sedang \\
5 & $10-20 \%$ & Kurang \\
6 & $0-10 \%$ & Sangat Kurang \\
\hline
\end{tabular}

Sumber: Mahmudi (2010:145)

\section{HASIL DAN PEMBAHASAN}

Untuk mempermudah dan memperjelas pemahaman mengenai penelitian ini, maka dideskripsikan hasil analisis statistik dari masing-masing wajib pajak restoran dalam penelitian ini. Statistik disajikan untuk memberikan informasi mengenai karakteristik wajib pajak restoran penelitian, yaitu jumlah sampel, nilai maksimum, nilai minimum, nilai rata-rata dan standar deviasi. Hasil statistik deskriptif dapat dilihat pada Tabel 4, Tabel 5, Tabel 6, dan Tabel 7, sebagai berikut.

Tabel 4, menjelaskan bahwa wajib pajak restoran yang mencakup restoran, rumah makan, dan bar. Pada restoran jumlah kursi minimum sebanyak 12 buah kursi dan maksimum sebanyak 384 buah kursi dengan rata-rata jumlah kursi 
pada restoran sebanyak 61 buah kursi dan standar deviasi pada jumlah kursi sebanyak 45 buah kursi. Jumlah kursi minimum pada sebuah rumah makan sebanyak 20 buah kursi dan maksimum sebanyak 75 buah kursi dengan rata-rata jumlah kursi pada rumah makan sebanyak 21 buah kursi dan standar deviasi jumlah kursi pada rumah makan sebanyak 9 buah kursi. Serta pada bar jumlah kursi minimum sebanyak 100 buah kursi dan jumlah kursi maksimum sebanyak 100 buah kursi dengan rata-rata jumlah kursi sebuah bar sebanyak 100 buah kursi dan standar deviasi pada sebuah bar sebesar 35 buah kursi.

Tabel 4. Hasil Statistik Deskriptif Jumlah Kursi Wajib Pajak Restoran

\begin{tabular}{lllll}
\hline \multirow{2}{*}{ Klasifikasi } & \multicolumn{3}{c}{ Jumlah Kursi } \\
& Minimum & Maksimum & Rata-rata & $\begin{array}{l}\text { Standar } \\
\text { Devisiasi }\end{array}$ \\
\hline Restoran & 12 & 384 & 61 & 45 \\
Rumah Makan & 20 & 75 & 21 & 9 \\
Bar & 100 & 100 & 100 & 35 \\
\hline
\end{tabular}

Sumber: Data Penelitian, 2019

Tabel 5, menjelaskan hasil statistik deskriptif tarif harga makan dan minum wajib pajak restoran. Pada restoran yang berjumlah 141 buah restoran, harga minimum makan dan minum sebesar Rp40.000 dan harga maksimum makan dan minum sebesar Rp325.000 dengan rata-rata harga makan dan minum sebesar Rp118.262 dan standar deviasi harga mkan dan minum sebesar Rp50.376,21. Harga minimum makan dan minum di rumah makan yang berjumlah 42 rumah makan sebesar Rp25.000 dan harga maksimum makan dan minum sebesar Rp100.000 dengan rata-rata harga makan dan minum sebesar Rp53.607 dan standar deviasi harga makan dan minum sebesar Rp19.893,48. Serta pada yang berjumlah 2 bar, harga minimum makan dan minum sebesar Rp100.000 dan harga maksimum makan dan minum sebesar Rp300.000 dengan rata-rata harga makan dan minum sebesar Rp200.000 dan standar deviasi harga makan dan minum sebesar Rp141.421,36.

Tabel 5. Hasil Statistik Deskriptif Tarif Harga Makan dan Minum Wajib Pajak Restoran

\begin{tabular}{lllll}
\hline \multirow{2}{*}{ Klasifikasi } & \multicolumn{3}{c}{ Tarif Harga Makan dan Minum } \\
\cline { 2 - 5 } & Minimum & Maksimum & Rata-rata & $\begin{array}{l}\text { Standar } \\
\text { Deviasi }\end{array}$ \\
\hline Restoran & 40.000 & 325.000 & 118.262 & $50.376,21$ \\
Rumah Makan & 25.000 & 100.000 & 53.607 & $19.893,48$ \\
Bar & 100.000 & 300.000 & 200.000 & $141.421,36$ \\
\hline
\end{tabular}

Sumber: Data Penelitian, 2019

Tabel 6, menjelaskan hasil statistik deskriptif mengenai jam efektif saat pengunjung datang. Pada restoran jam efektif minimum saat pengunjung datang selama 2 jam dan jam efektif maksimum saat pengunjung datang selama 5 jam dengan rata-rata jam efektif saat pengunjung datang selama 3 jam. Jam efektif minimum saat pengunjung datang pada rumah makan selama 2 jam dan jam efektif maksimum saat pengunjung datang selama 4 jam dengan rata-rata jam efektif saat pengunjung datang selama 3 jam. Serta pada bar jam efektif minimum saat pengunjung datang selama 4 jam dan jam efektif maksimum selama 4 jam dengan rata-rata jam efektif saat pengunjung datang selama 4 jam. 
Tabel 6. Hasil Statistik Deskriptif Jam Efektif Wajib Pajak Restoran

\begin{tabular}{lllll}
\hline \multirow{2}{*}{ Klasifikasi } & \multicolumn{3}{c}{ Jam Efektif } \\
\cline { 2 - 5 } & Minimum & Maksimum & Rata-rata & $\begin{array}{l}\text { Standar } \\
\text { Devisiasi }\end{array}$ \\
\hline Restoran & 2 jam & 5 jam & 3 jam & 1 jam \\
Rumah Makan & 2 jam & 4 jam & 3 jam & 1 jam \\
Bar & 4 jam & 4 jam & 4 jam & - \\
\hline
\end{tabular}

Sumber: Data Penelitian, 2019

Tabel 7, menjelaskan mengenai hasil statistik deskriptif jam tidak efektif saat pengunjung datang. Pada restoran, jam tidak efektif minimum saat pengunjung datang selama 3 jam dan jam tidak efektif maksimum saat pengunjung datang selama 19 jam dengan rata-rata jam tidak efektif saat pengunjung datang selama 9 jam. Pada rumah makan, jam tidak efektif minimum saat pengunjung datang selama 2 jam dan jam tidak efektif maksimum saat pengunjung datang selama 20 jam dengan rata-rata jam tidak efektif saat pengunjung datang selama 8 jam. Serta pada bar, jam tidak efektif saat pengunjung datang selama 10 jam dan maksimum jam tidak efektif saat pengunjung datang selama 13 jam dengan rata-rata jam tidak efektif saat pengunjung data selama 12 jam.

Tabel 7. Hasil Statistik Deskriptif Jam Tidak Efektif Wajib Pajak Restoran

\begin{tabular}{lllll}
\hline \multirow{2}{*}{ Klasifikasi } & \multicolumn{3}{c}{ Jam Tidak Efektif } \\
\cline { 2 - 5 } & Minimum & Maksimum & Rata-rata & $\begin{array}{c}\text { Standar } \\
\text { Deviasi }\end{array}$ \\
\hline Restoran & 3 jam & 19 jam & 9 jam & 2 jam \\
Rumah Makan & 2 jam & 20 jam & 8 jam & 3 jam \\
Bar & 10 jam & 13 jam & 12 jam & 2 jam \\
\hline
\end{tabular}

Sumber: Data Penelitian, 2019

Perhitungan potensi pajak restoran di Kecamatan Kuta Utara dilakukan dengan langkah menghitung rata-rata jumlah pengunjung per hari yang datang. Perhitungan rata-rata jumlah pengunjung dapat dihitung dengan menjumlah perhitungan jumlah kursi dikali jam efektif pada saat pengunjung datang yang di dapatkan berdasarkan wawancara dikali tingkat pengunjung efektif dengan perhitungan jumlah kursi dikali jam tidak efektif dikali tingkat pengunjung tidak efektif.

Setelah mendapatkan rata-rata pengunjung per hari, selanjutnya dapat menghitung dasar pengenaan pajak restoran di Kecamatan Kuta Utara. Menghitung dasar pengenaan untuk pajak restoran dapat dihitung dengan mengalikan rata-rata pengunjung per hari, harga rata-rata makan dan minum per orang, dan jumlah hari.

Perhitungan potensi pajak restoran di Kecamatan Kuta Utara dapat dihitung dengan mengalikan dasar pengenan pajak restoran dikali tarif pajak restoran sebesar 10 persen. Hasil dari perhitungan tersebut dapat dilihat pada Tabel 8, sebagai berikut.

Berdasarkan hasil perhitungan potensi, total potensi penerimaan Pajak Restoran di Kecamatan Kuta Utara adalah sebesar Rp94.143.988.800 atau 212,7 persen dibandingkan dengan Realisasi Pajak Restoran Tahun 2018. Potensi penerimaan Pajak Restoran dihitung dari total potensi penerimaan Pajak Restoran sebesar Rp88.406.020.800 dengan jumlah restoran sebanyak 141, Pajak 
Rumah Makan sebesar Rp3.280.968.000 dengan jumlah rumah makan sebanyak 42 dan Pajak Bar sebesar Rp2.457.000.000 dengan jumlah bar sebanyak 2, yang menjadi wajib pajak di Kecamatan Kuta Utara.

Tabel 8. Potensi Pajak Restoran di Kecamatan Kuta Utara Kabupaten Badung Tahun 2019

\begin{tabular}{cccc}
\hline Jenis Restoran & $\begin{array}{c}\text { Dasar Pengenaan } \\
\text { Pajak (Rp) }\end{array}$ & Tarif Pajak & $\begin{array}{c}\text { Potensi Pajak } \\
\text { Restoran Tahun } \\
2019(\mathrm{Rp})\end{array}$ \\
\hline Restoran & 884.060 .208 .000 & $10 \%$ & 88.406 .020 .800 \\
Rumah Makan & 32.809 .680 .000 & $10 \%$ & 3.280 .968 .000 \\
Bar & 24.570 .000 .000 & $10 \%$ & 2.457 .000 .000 \\
Total & 941.439 .888 .000 & & 94.143 .988 .800 \\
\hline
\end{tabular}

Sumber: Data Penelitian, 2019

Realisasi pajak restoran di Kecamatan Kuta Utara di proporsikan berdasarkan jumlah kursi wajib pajak restoran. Jumlah kursi di Kecamatan Kuta Utara berjumlah 9.632 buah kursi di bagi jumlah kursi wajib pajak restoran di Kabupaten Badung berjumlah 135.896 buah kursi di kalikan realisasi pajak restoran di Kabupaten Badung Tahun 2018 sebesar Rp624.456.631.009. Jadi hasil realisasi pajak restoran di Kecamatan Kuta utara sebesar Rp44.260.068.507. Begitu pula dengan target pajak restoran di Kecamatan Kuta Utara, di proporsikan berdasarkan jumlah kursi wajib pajak restoran. Target pajak restoran di Kecamatan Kuta Utara sebesar Rp41.004.140.372 di dapat dari pembagian jumlah kursi wajib pajak restoran di Kecamatan Kuta Utara yang berjumlah 9.632 buah kursi dengan jumlah kursi wajib pajak restoran di Kabupaten badung yang berjumlah 135.896 buah kursi di kalikan dengan target pajak restoran di Kabupaten Badung Tahun 2018 sebesar Rp579.083.731.320.

Perhitungan efektivitas pemungutan pajak restoran di Kecamatan Kuta Utara di dapat berdasarkan realisasi pajak restoran di Kecamatan Kuta Utara sebesar Rp44.260.068.507 di bagi target pajak restoran di Kecamatan Kuta Utara sebesar Rp41.004.140.372 dan di kali 100 persen. Hasil presentase perhitungan efektivitas pemungutan pajak restoran di Kecamatan Kuta Utara mencapai 107,84 persen yang memiliki kriteria sangat efektif dalam pemungutan pajak restoran di Kecamatan Kuta Utara. Efektivitas pemungutan pajak restoran apabila berdasarkan perbandingan realisasi pajak restoran Tahun 2018 sebesar Rp44.260.068.507 dengan potensi pajak restoran Tahun 2019 sebesar Rp94.143.988.800, efektivitas pemungutan pajak restoran mencapai 47,01 persen yang memiliki kriteria tidak efektif dalam pemungutan pajak restoran di Kecamatan Kuta Utara.

Pendapatan Asli Daerah di Kabupaten Badung Tahun 2018 sebesar Rp5.272.457.400.000. Perhitungan kontribusi pajak restoran di Kecamatan Kuta Utara dilakukan dengan cara membagi realisasi pajak restoran di Kecamatan Kuta Utara Tahun 2018 sebesar Rp44.260.068.507 dengan Pendapatan Asli Daerah di Kabupaten Badung Tahun 2018 sebesar Rp5.272.457.400.000 dikali dengan 100 persen. Hasil presentase perhitungan kontribusi pajak restoran di Kecamatan Kuta Utara mencapai 0,84 persen dari total Pendapatan Asli Daerah di Kabupaten Badung Tahun 2018. 
Perhitungan kontribusi pajak restoran berdasarkan realisasi pajak restoran tahun 2018 dengan pajak daerah tahun 2018. Perhitungan kontribusi pajak restoran di Kecamatan Kuta Utara dengan membagi realisasi pajak restoran di Kecamatan Kuta Utara sebesar Rp44.260.068.507 dengan pajak daerah di Kabupaten Badung sebesar Rp4.989.883.606.261 dikali dengan 100 persen. Hasil presentase perhitungan kontribusi pajak restoran di Kecamatan Kuta Utara mencapai 0,89 persen dari total Pajak Daerah di Kabupaten Badung Tahun 2018.

Potensi pajak merupakan hasil temuan pendataan di lapangan yang berkaitan jumlah serta frekuensi obyek pajak yang kemudian dikalikan dengan tarif dasar pajak. Potensi Pajak sangat menentukan besarnya pajak daerah yang dapat dipungut, dengan demikian besarnya potensi pajak perlu diketahui untuk menetapkan besarnya target penerimaan pajak pada suatu periode. Dapat diketahui bahwa besarnya potensi pajak restoran Kecamatan Kuta Utara tahun 2019 adalah Rp94.239.676.800,00 atau 212,7 persen apabila dibandingkan dengan Realisasi Pajak Restoran Tahun 2018. Besarnya potensi pajak sangatlah berbeda dengan realisasi Pajak Restoran Kecamatan Kuta Utara pada tahun 2018 yaitu sebesar Rp44.260.068.507. Hal ini menunjukkan bahwa banyak potensi pajak restoran di Kecamatan Kuta Utara yang belum digali. Dengan keadaan yang demikian, maka potensi yang diukur dengan target yang ditentukan jauh dari yang sesungguhnya ada.

Efektivitas menunjukkan tingkat keberhasilan atau kegagalan untuk mencapai tujuan, sehingga efektivitas hanya mengukur dari segi output. Efektivitas pemungutan pajak restoran di Kecamatan Kuta Utara bila diukur dengan realisasi pajak restoran Tahun 2018 dan potensi pajak restoran mencapai 47,01 persen yang menunjukan bahwa pemungutan pajak restoran di Kuta Utara memiliki kriteria tidak efektif. Hal ini menunjukan bahwa potensi pajak restoran lebih besar dari target pajak restoran Tahun 2018 yang telah ditetapkan.

Kontribusi pajak restoran terhadap Pendapatan Asli Daerah Kecamatan Kuta Utara dihitung dengan membandingkan jumlah realisasi penerimaan pajak restoran dengan jumlah penerimaan Pendapatan Asli Daerah di Kecamatan Kuta Utara. Dapat diketahui pajak restoran di Kecamatan Kuta Utara memberikan kontribusi sebesar 0,84 persen dari total penerimaan Pendapatan Asli Daerah di Kabupaten Badung Tahun 2018 sebesar Rp5.272.457.400.000.

Kontribusi pajak restoran terhadap pajak daerah di Kabupaten Badung Tahun 2018 dihitung berdasarkan realisasi pajak restoran di Kecamatan Kuta Utara Tahun 2018 dengan pajak daerah di Kabupaten Badung Tahun 2018. Hasil dari perhitungan tersebut, dapat diketahui pajak restoran memberikan kontribusi sebesar 0,89 persen dari total pajak daerah di Kabupaten Badung Tahun 2018 sebesar Rp4.989.883.606.261.

\section{SIMPULAN}

Berdasarkan hasil analisis dapat disimpulkan bahwa potensi pajak restoran di Kecamatan Kuta Utara Tahun 2019 sebesar Rp94.239.676.800 atau 212,7 persen dibandingkan dengan realisasi Pajak Restoran di Kecamatan Kuta Utara Tahun 2018. Efektivitas pemungutan pajak restoran di Kecamatan Kuta Utara Tahun 2018 sebesar 47,01 persen (perbandingan antara realisasi pajak restoran Tahun 2018 dengan potensi Pajak Restoran) digolongkan tidak efektif. Hal ini 
menunjukan bahwa potensi pajak restoran lebih besar dibandingkan realisasi pajak restoran Tahun 2018. Realisasi Pajak restoran di Kecamatan Kuta Utara Tahun 2018 memberikan kontribusi sebesar 0,84 persen pada total Pendapatan Asli Daerah di Kabupaten Badung Tahun 2018. Realisasi pajak restoran di Kecamatan Kuta Utara Tahun 2018 menyumbang 0,88 persen pada total Pajak Daerah Tahun 2018.

\section{REFERENSI}

Abdul, H. (2007). Bunga Rampai Manajemen Keuangan Daerah: Pengelolaan Keuangan Daerah (2nd ed.). Yogyakarta: UPP AMP YKPN.

Andeman. (2001). Potensi Pajak Hotel dan Restoran Kota Bukittinggi. Universitas Gajah Mada.

Aragon, F. (2009). Economic Organisation and Public Policy Discussion Paper The Flypaper Effect Revisited The Flypaper Effect Revisited. Sticerd London Of School Of Economic, 4.

Ardhiansyah, D. (2014). Analisis Potensi Pajak Hotel Dan Pajak Restoran Dan Kontribusinya Terhadap Pendapatan Asli Daerah (PAD) (Studi Kasus pada Dinas Pendapatan Daerah Kota Batu Tahun 2011-2013). Jurnal Administrasi Bisnis, 14(1).

Chau, G., \& Leung, P. (2009). A critical review of Fischer tax compliance model : A research synthesis. Journal of Accounting and Taxation, 1(2), 034-040. https://doi.org/10.5897/JAT09.021

Devos, K. (2009). An Investigation Into Australian Personal Tax Evaders- Their Attitudes Towards Compliance And The Penalties For Non-Compliance An Investigation Into Australian Personal Tax Evaders- Their Attitudes. Revenue Law Journal, 19(1), Article 2.

Diana. (2010). Perpajakan Indonesia, Konsep Aplikasi dan Penuntun Praktis. Yogyakarta: Andi.

Djarwanto. (2000). Analisis Laporan Keuangan. Yogyakarta: BPFE

Engida, G. T. (2004). Factors Influencing taxpayers' compliance with the tax system: An empirical study in Mekelle City, Ethiopia. EJournal of Tax Research, 2(1), 8-70.

Erly, S. (2005). Hukum Pajak (3rd ed.). Jakarta: Salemba Empat.

Handoko, S. (2013). Analisis Tingkat Efektivitas Pajak Daerah Sebagai Sumber Pendapatan Asli Daerah Kota Pontianak. Jurnal Ilmiah.

Halim, Abdul. (2004). Bunga Rampai Manajemen Keuangan Daerah. Edisi Revisi. Yogyakarta: UPP AMP YKPN.

Harun, H Hamrolie. (2003). Menghitung Potensi Pajak dan Retribusi Daerah. Yogyakarta: BFFE-Yogyakarta.

Hasanudin. (2015). Analisis Efektivitas dan Kontribusi Pajak Kendaraan Bermotor Terhadap Penerimaan Pendapatan Asli Daerah di Provinsi Maluku Utara. Skripsi Program Studi Akuntansi Universitas Samratulangi.

James, S., \& Alley, C. (2009). Tax Compliance , Self-Assessment and Tax Administration School of Business and Economics, University of Exeter. Journal of Finance and Management in Public Services, 2(2), 27-42.

Kamaroellah, A. (2011). Retribution Revenue Contribution Analysis Of Marketing Revenue at Pamekasan District Revenue Office. Jurnal Ekonomika, 
$4(1)$.

Lestari, G. A. Widya., \& Putri, I. G. A. M. Asri Dwija. (2017). Pengaruh Corporate Governance, Koneksi Politik, Dan Leverage Terhadap Penghindaran Pajak. E-Jurnal Akuntansi Universitas Udayana Vol.18.3., 18(3), 2028-2054.

Mahmudi. (2010). Analisis Laporan Keuangan Pemerintah Daerah. Sekolah Tinggi Ilmu Manajemen. Yogyakarta.

Makalew, M. D., Nangoi, G. B., \& Lambey, R. (2018). Analisis Potensi Dan Efektivitas Penerimaan Pajak Restoran Di Kota Tomohon. Jurnal Riset Akuntansi Going Concern, 13(2), 57-67.

Mardiasmo. (2018). Perpajakan (Edisi Terbaru). Yogyakarta: ANDI

Martin, Lumumba Omweri, Migwi S.Wanjohi, Obara Magutu, \& John Mageto Makoro. (2010). Taxprayer Attitudes and Tax Compliance Behavior in Kenya. African Journal of Business \& Management, 1, 112-122.

Marziana Bt. Hj. Mohamad, Norkhazimah Bt. Ahmad, \& Mohmad Sakarnor Bin Deris. (2010). The Reletionship Between Perceptions and level of compliance Under Self Assessment System-A Study in The East Coast Region. Journal of Global Business and Economic, 1(1), 241-257.

Niemirowski, P., Baldwin, S., \& Wearing, A. J. (2003). Tax Related Behaviours, Beliefs, Attitudes and Values and. Journal Of Australian Taxation, 6(1), 132165.

Norregaard, J. (2013). Taxing Immovable Property Revenue Potential and Implementation Challenges. IMF Working Papers, 13(129), 1. https://doi.org/10.5089/9781484369050.001

Pepinsky, T. B., \& Wihardja, M. M. (2011). Decentralization and economic performance in Indonesia. Journal of East Asian Studies, 11(3), 337-371. https://doi.org/10.1017/S1598240800007372

Poulson, B. W., \& Kaplan, J. G. (2008). State income taxes and economic growth. Cato Journal, 28(1), 53-70.

Pratamawaty, B. B., Cahyadini, A., Julianja, S., \& Veronica, G. S. (2019). Policy Communication Strategy of Restaurant Tax to Increase Bandung's OwnSource Revenue. IOP Conference Series: Earth and Environmental Science, 248(1). https:// doi.org/10.1088/1755-1315/248/1/012068

Peraturan Daerah Nomor 15 Tahun 2018 Tentang Tata Cara Penagihan Pajak Daerah.

Peraturan Daerah Nomor 16 Tahun 2011 Tentang Pajak Restoran.

Prakosa, Bambang. (2005). Pajak dan Retribusi Daerah. Yogyakarta: UII Press.

Rahyuda, I. K., Murjana Yasa, I. G. W., \& Yuliartini, N. N. (2004). Metodologi Penelitian. Universitas Udayana.

Ratnadi, N. M. D., \& Widanaputra, A. A. G. P. (2019). Pengaruh Persepsi Kegunaan, Kemudahan Penggunaan dan Norma Subyektif pada Minat Berperilaku Penggunaan E-Billing. Jurnal Ilmiah Akuntansi Dan Bisnis, 14(2), 169. https://doi.org/10.24843/jiab.2019.v14.i02.p03

Republik Indonesia. Undang-Undang Nomor 28 Tahun 2009 tentang Pajak Daerah dan Retribusi Daerah. Lembaran Negara Republik Indonesia Tahun 2009 Nomor 130.

Republik Indonesia, Undang-Undang Nomor 32 Tahun 2004 tentang Pemerintahan Daerah. Lembaran Negara Republik Indonesia Tahun 2004 Nomor 125. 
Republik Indonesia, Undang-Undang Nomor 33 Tahun 2004 tentang Perimbangan Keuangan antara Pemerintah Pusat dan Pemerintah Daerah. Lembaran Negara Republik IndonesiaTahun 2004 Nomor 126.

Siahaan, M. P. (2010). Pajak Daerah dan Retribusi Daera. Jakarta: PT.Rajagrafindo Persada.

Sugiyono. (2017). Metode Penelitian Kuantitatif, Kualitatif, dan RED. Bandung: Alfabeta, CV.

Sugiyono. (2018). Metode Penelitian Manajemen. Bandung: Alfabeta,CV.

Supadmi, Ni Luh. (2009). Meningkatkan Kepatuhan Wajib Pajak Melalui Kualitas Pelayanan. Jurnal Ilmiah Akuntansi Dan Bisnis, 1-14.

Tahar, A., \& Rachman, A. K. (2016). Pengaruh Faktor Internal dan Faktor Eksternal Terhadap Kepatuhan Wajib Pajak. Jurnal Akuntansi Dan Investasi, 15(1), 56-67.

Tjip, I. (2011). Paradigm Change of Local Tax. Journal of Administraitive Science $\mathcal{E}$ Organization, 18(1), 33-42.

Waluyo. (2007). Perpajakan Indonesia. Yogyakarta: Salemba Empat.

Warsito. (2001). Hukum Pajak. Jakarta: PT. Rajawali Grafindo Persada.

Wirawati, N. G. P., \& Putra, I. N. W. A. (2019). Analysis Of Factors That Influence The Compliance Of Tax And Restaurant Taxes In Tabanan Regency Of Bali, Indonesia. RJOAS: Russian Journal of Agricultural and Socio-Economic Sciences, $86(2), 216-227$.

Wong, J. D. (2004). The fiscal impact of economic growth and development on local government revenue capacity. Journal of Public Budgeting, Accounting $\mathcal{E}$ Financial Management, 16(3), 413-423. https://doi.org/10.1108/jpbafm-1603-2004-b006 